Ciolkovskij, K. Je. (1986) Grjozy o zemle i nebe: Nauchno-fantasticheskie proizvedenija. Tula, Prioksky Book Publishing House. 448 p. (In Russ.).

Ciolkovskij, K. Je. (2001a) Kosmicheskaja filosofija / ed. by D. N. Popov. Moscow, URSS. 487 p. (In Russ.).

Ciolkovskij, K. Je. (2001b) Ocherki o Vselennoj. Kaluga, Zolotaja alleja. 384 p. (In Russ.).

Ciolkovskij, K. Je. (2009) Prikljuchenija atoma. Moscow, Luch. 112 p. (In Russ.).

Chizhevskij, A. L. (1974) Vsja zhizn'. Moscow, Sovetskaja Rossija. 208 p. (In Russ.).

Chizhevskij, A. L. (1995) Na beregu Vselennoj. Moscow, Mysl'. 735 p. (In Russ.).

Submission date: 15.07.2021.

Ишутин Александр Александрович - кандидат филологических наук, доцент кафедры фундаментальных юридических и социально-гуманитарных дисциплин Московского финансово-промышленного университета «Синергия». Адрес: 105318, Россия, г. Москва, ул. Измайловский вал, д. 2. Тел.: 8 (495) 800-10-01. Эл. адрес: a_ishutin@inbox.ru

Ishutin Aleksandr Aleksandrovich, Candidate of Philology, Associate Professor, Department of Fundamental Legal and Social-Humanitarian Sciences, Moscow Industry and Finance University "Synergy". Postal address: 2, Izmaylovsky Val St., Moscow, Russian Federation, 105318. Tel.: 8 (495) 800-10-01. E-mail: a_ishutin@inbox.ru

DOI: $10.17805 /$ zpu.2021.3.6

\title{
Ценностная сущность русского героического эпоса: проблемы и перспективы исследования
}

\author{
А. С. МИРОНОВ \\ МОСКОВСКИЙ ГОСУДАРСТВЕННЫЙ ИНСТИТУТ КУЛЬТУРЫ
}

Исследователи русского героического эпоса, по мнению автора статьи, оказываются не в состоянии продвинуться в решении проблемы происхождения и жанровой функции былины, их связи с мифологическим сознанием, величальной поэзией, различными архаическими обрядами и ритуалами без обращения к инструментарию философии культуры, для которой одним из ключевых является метод комплексного аксиологического анализа. Объектом такого анализа должны стать как совокупность ценностей, мотивирующих действия всех героев русского эпоса, так и - гипотетически - элементы мировоззрения, общие для большинства сказителей, иными словами - картина мира русского эпического сознания.

Автор статьи полагает, что русский эпический певец принимает на себя роль созерцателя и оценивает ценностный выбор героя не напрямую, но посредством подбора вариантов, демонстрирующих действие тех или иных духовных законов по модели «поступокпоследствия», при этом мотивируя активную критическую деятельность слушателя, связанную с необходимостью «переоценивания» поступков, совершенных героем. Следовательно, исследование того, как изменяется в ценностном центре слушателя «курс» мотивировавшей героя ценности, открывает перспективу для изучения ценностной сущности русских былин как взаимосвязанного единства и предполагает, в частности, возможность моделировать эпическое мировоззрение русских. 
Ключевые слова: былины; комплексный аксиологический анализ; ценности; поступок; мотивация; мировоззрение; эпическое сознание

\section{ВВЕАЕНИЕ}

$\mathrm{H}_{\mathrm{c}}^{\mathrm{a}}$ ачиная с середины XIX в. исследователи былин, пытаясь выявить сущность русского героического эпоса, вводят такие категории, как «народные идеалы», «народные понятия» (Шевырев, 1840: 190, 234), «духовное содержание» былин (Белинский, 1954: 427), добрые и злые «начала» (Аксаков, 1856: 10), «лучшие нравственные понятия и стремления» (Майков, 1863: 124), «народный характер» (Гильфердинг, 1894: 24-25), единый «взгляд на все в мире» (Оксенов, 1908: 5), призывают изучить отразившееся в былинах «миросозерцание носителей» эпической традиции (Сперанский, 1919: XVIII), «народные чаяния и надежды» (Соколов, 1937: 184-185), «этические черты», «общеморальные или национальные или классовые оценки» (Скафтымов, 1924: 95, 101), «вековые идеалы и стремления народа» (Пропп, 1958: 27; курсив источника. - A. M.), относящиеся к определенным этапам русской истории. Отечественные и иностранные исследователи усматривают в фольклоре как таковом глубинные исторические и экзистенциальные смыслы, «символику судеб народа, имеющую первостепенное значение для построения философии истории и для постижения внутреннего ее смысла» (Бердяев, 1969: 33), выявляют представления, которые уходят «в глубь самой сущности русской народности и русского искусства» (цит. по: Соколов, 1929: 35-36), исследуют «социальные нормы и нравственные суждения», а также «качества, наиболее обожаемые в герое» русским народом (Chadwick H., Chadwick N., 1936: 38), и, наконец, обнаруживают в былинах «религиозную схему ценностей» (Bowra, 1952: 24). И. А. Ильин, говоря о задачах национального воспитания будущей России, писал о важности «преклонения перед святым и героем», которое возникает в результате знакомства новых поколений с житийной литературой и фольклорным эпосом (Ильин, 1993: 204). По убеждению философов культуры, историков, филологов, этнографов, эпос «знает одно-единое и единственное сплошь готовое мировоззрение» (Бахтин, 2000: 226); он отражает народное мировоззрение, потому что содержит оценку исторического прошлого (Иихачев, 1953: 183-184).

Последователи историко-типологического направления, так называемые ритуалисты, применявшие метод структурного анализа, полагали, что эпос хранит «сумму представлений о мире» (Топоров, 1982: 161), специфические «эпические идеалы» (Мелетинский, 1986: 63), формирующие «аксиологически ориентированную модель мира» (Мелетинский, 1976: 13). Сторонники исторической школы соглашались со своими оппонентами в том, что героический әпос является «нравственным кодексом», возвеличивает «социальные и нравственно-этические идеалы народа» (Аникин, 1964: 10-11); Ф. М. Селиванов полагал, что былины утверждают «социально-патриотические и нравственные идеалы» (Селиванов, 1983: 57), а по убеждению А. А. Горелова, «былинные произведения явились одним из важнейших факторов, обеспечивавших консолидацию русской нации и русской государственности» (Горелов, 2001: 11). Этнографы и фольклористы приходят к выводу о том, что былины отражают «систему мировоззрения и народных представлений», основу которой составляет другая система - «ритуальных функций и текстов» (Толстой, 1989: 11). Ведущие представители семиотической школы в свою очередь пытаются выявить «основные культурные ценности (идеологические, политические, религи- 
озные)» русского средневекового сознания, описать «ценностное поле» русской культуры, в том числе традиционной народной (Иотман, Успенский, 1996: 339). Ученые, впрочем, оказываются не в состоянии продвинуться в решении проблемы русского эпоса без обращения к инструментарию философии культуры, для которой одним из ключевых является метод комплексного аксиологического анализа. Объектом такого анализа должна стать как совокупность ценностей, мотивирующих действия всех героев русского эпоса, так и - гипотетически - элементы мировоззрения, общие для большинства сказителей, иными словами - картина мира русского эпического сознания.

Хотя практический опыт инкультурации ценностей традиционной культуры уже хорошо изучен и описан, результаты существующих исследований не позволяют сузить перечень подобных ценностей, сколько-нибудь точно и последовательно описать их. Аля русского героического эпоса этот набор варьирует - от милосердия, сострадания (Шевырев, 1840: 190) до бездуховной физической силы, безрассудной удали и молодечества (Белинский, 1954: 426-427); от разрушения личного начала и подавляющей личность религиозности (Bowra, 1952: 346) до личной корысти (Chadwick H., Chadwick N., 1936: 99), «гуманизма», «выдающегося здоровья» (Плисецкий, 1962: 17) и «здорового жизнеутверждающего мировоззрения» (Адрианова-Перетц, 1974: 26); от «социальной активности», «принесения пользы народу, человечеству, коллективу» (Плисецкий, 1962: 34) - до «фатализма» (Сиротинин, 1913: 148-149), «тщательно аргументированной пассивности» (Харитонов, 1997: 15), от «ненасильственности» и семейных ценностей (Аксаков, 1861: 385) - до безусловного примата защиты родины, патриотизма, завоевания чужих земель (Аникин, 1980: 234), победы в захватнических войнах (Самбур, 2010: 17).

\section{МЕТОАОАОГИЯ ЦЕННОСТНОГО АНААИЗА РУССКИХ БЫАИН}

С нашей точки зрения, чтобы сформулировать определение ценности применительно к эпическому сознанию, необходимо уточнить знаменитый вопрос Сократа («что есть благо?») следующим образом: «что есть благо для әпического героя?», «что есть благо для эпического певца?» Не вызывает сомнений, что главной чертой эпического протагониста является то, что он наделен особенной силой (не обязательно физической - это может быть колдовская сила, хитроумие и др.). С известным допущением можно сказать, что ключевой проблемой эпоса является проблема силы. Вопрос о том, как должно использовать эпическую силу, оправданно поставить следующим образом: что наиболее полезное, ценное можно получить «в обмен» на нее? Заметим, что акт такого «обмена» необходим, иначе эпический герой не проявит себя как герой, и сама песнь не состоится в композиционном плане.

Аругой характерной чертой героического эпоса является то, что поступки его персонажей преимущественно связаны с риском для жизни: обладание силой делает доступными для героя те блага, которые едва ли достижимы для большинства людей (потому что «цена» этих благ превышает стоимость человеческой жизни). Только наличие чудесной силы позволяет әпическому герою рассчитывать на успех; опыт «добывания» высших благ, едва ли доступных обычным людям, и составляет предмет героического эпоса.

Исследуя ценности эпической поэзии, целесообразно разделять их - вслед за Аристотелем и целым рядом других философов - на конечные, предельные, терминальные (у Аристотеля - цели-результаты, в $\gamma \alpha$ ) и инструментальные, служеб-

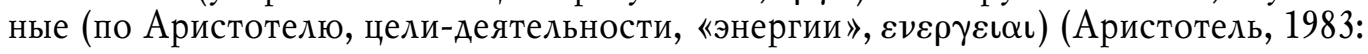


54-55). Первый род ценностей Аристотель полагал целью, ради которой желанны

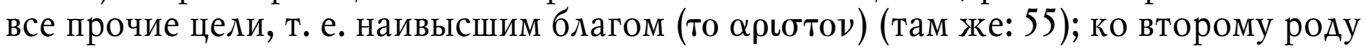
ценностей автор «Никомаховой этики» относия, в частности, все «умения» $(\delta v v \alpha \mu \iota \zeta)$ человека (там же: 55). В процессе анализа важно различать, направлено ли действие әпического героя на достижение цели, связанной с конечной ценностью, или же «целевая» ценность является лишь средством для достижения ценности более высокого ранга.

Итак, для того чтобы выделить и описать те или иные аксиологические категории в эпическом произведении, необходимо принять во внимание следующее:

во-первых, ценность дана слушателю только с связи с актом «обмена» (предпочтения);

во-вторых, предельная ценность есть нечто, на что герой соглашается «обменять» собственное существование; следовательно, такая ценность является началом, превышающим для героя цену его жизни и потому мотивирующим его на поступок, связанный с высокой вероятностью смерти;

в-третьих, инструментальная ценность есть начало, не превышающее для героя цену его жизни, однако сопоставимое с этой ценой - в силу того, что, обладая подобной ценностью, герой получает возможность избежать «обмена» предельной ценности на собственную жизнь непосредственно. Таким образом, в «снятом» виде инструментальная ценность оказывается равна той цене, которую имеет жизнь героя, - не будучи при этом целью «обмена», но лишь «замещая» собой цену жизни. Иными словами, благодаря инструментальной ценности герой получает возможность достичь ценности предельной, не потеряв при этом собственную жизнь.

Аристотель полагал, что «обмен» жизни на некую высшую ценность вызван не любовью к әтой ценности, но самой по себе необходимостью умереть и страхом «разменять» свою жизнь на смерть недостойную (там же: 115). Однако такое понимание «обмена» замещает само определяемое понятие - вместо ценности Аристотель говорит о смысле, на основании которого производится рассудочный акт «обмена»; однако в отличие от смысла категория ценности может быть связана не с рассудочным актом, но с «вожделеющим» актом сердца (ощущение высочайшей значимости, свойственной «внешнему» объекту, дается в акте сердечного чувства). Следовательно, один и тот же акт - например, смерть в бою ради соплеменников - может быть и актом сердечной работы (в рассматриваемом случае - сострадания), и актом рассудочного «обмена» своей жизни на ту или иную на высшую ценность ( ООтечество») с целью поднять собственную «стоимость» в глазах потомков. Мы будем исходить из того, что герой готов «обменять» свою жизнь на некую высшую ценность не только потому, что боится закончить жизнь в тот момент, когда она будет недооценена окружающими, но и потому, что действительно ощущает, что высшая ценность обладает большей истинностью, чем его собственная жизнь. Таким образом, мера истинности объекта, степень полноты его бытия может как рассудочно постигаться героем, так и непосредственно ощущаться им.

В понимании эпического героя его собственная жизнь не обладает высшей мерой истинности (именно в силу своей временности, обреченности на смерть, а также в связи с постоянным риском обесценивания ввиду нежелательного «обмена»). Поэтому главной задачей героя становится использование своей чудесной силы для «добывания» чего-то, обладающего большей степенью истинного бытия (в этом смысле героический эпос есть песни о том, на что великие предки готовы были «обменять» свою жизнь). И здесь решающую роль играет поступок героя, который все- 
гда имеет характер добровольного «обмена» одной ценности (жизни, помноженной на чудесную силу) — на нечто более ценное. Уже Аристотель в «Никомаховой

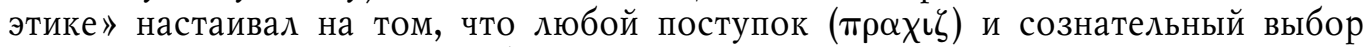

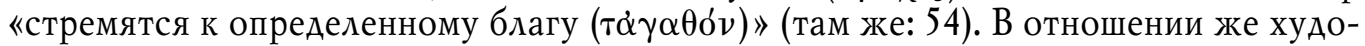
жественного мира эпоса вполне применимо наблюдение М. М. Бахтина о том, что именно вокруг поступка сосредоточены «все ценности действительной жизни и культуры», все «пространственно-временные и содержательно-смысловые ценности и отношения» (Бахтин, 2003b: 49-50). Отметим, что в әпосе эта роль поступка подчеркивается тем, что герой совершает сознательный выбор и стремится «обменять» собственную жизнь на некую высшую ценность.

Аля того чтобы различать ценности героя и ценности певца, мы используем понятие «ценностного центра», сформулированное М. М. Бахтиным: согласно ученому, ценностный центр есть «смысловая и оценивающая позиция человека по отношению к себе самому и по отношению к окружающей его действительности» (Бахтин, 2002: 56). В понимании М. М. Бахтина ценностный центр эпического певца сливается с ценностным центром эпического героя, т. е. реакция певца «направляется непосредственно на предмет и смысл, автор начинает познавать и поступать вместе с героем, но теряет художественное завершающее видение его» (Бахтин, 2003а: 80). Это наблюдение можно было бы считать очевидным, если бы единственным средством оценки, доступным эпическому певцу, было прямое морализаторство, т. е. непосредственно выраженная собственная оценочная позиция. Однако мы должны допустить и возможность того, что оценка певцом ценностного выбора своих героев реализуется в эпосе через демонстрацию тех последствий, которые этот выбор влечет за собой. В таком случае в центре внимания певца будет не оценка событий былины как таковых (т. е., например, не оценка поведения Аобрыни и Садко, Маринки Потравницы и Морского царя), но оценка реакции героя (Аобрыни - на поведение Маринки; Садко - на поведение Морского царя). Певец, исполняющий былину, не оценивает поступок героя непосредственно, но как бы «вглядывается» в оценку героем своего поступка, а также интересуется тем, насколько оценки героя соответствуют оценкам слушателя.

Выявление ценностей, мотивирующих каждого героя, - первоочередная задача аксиологического исследования былин, однако конечной и главной целью такого исследования является структурно-элементное описание ценностного центра эпического певца. В текстах былинных записей свойственные самому певцу ценности могут проявляться посредством различных оценочных суждений - включая формулирование ценностной категории, прямую оценку героя и его поступка (осуждение, одобрение, прославление и др.), в том числе при помощи оценочного эпитета, «выражения убежденностей или верований говорящего на основе его ценностного мотивационного отношения» (Серебренникова, 2011: 13), а также как отложенная во времени и раскрывающаяся в сюжете оценочная реакция певца на ценности героя (и его действия, вызванные этими ценностями) и, наконец, в рамках эпического подтекста.

Русскому былинному певцу не свойственны морализаторство и резонерство, он выступает почти исключительно в роли созерцателя; сказители устраняются от нравоучительной «авторской» позиции. В подавляющем большинстве былинных записей отсутствуют прямые оценки ценностного выбора, сделанного героем. В частности, И. С. Климас в исследовании «Русское фольклорное слово», изучив «оценочные характеристики человека» в отечественной лирике и в былинах, приходит 
к выводу о том, что в последнем случае крайне редко встречается оценка певцом моральных качеств своих персонажей (Климас, 2009; см. также: Климас, 2010).

Так называемые оценочные әпитеты, на которые указывал, в частности, B. Я. Пропп (Пропп, 1958: 527-531), в действительности весьма мало говорят слушателю о том, как певец оценивает ценностное предпочтение (поступок) героя в конкретном сюжете. В. Я. Пропп полагает, что действующие лица в былинах строго делятся на добрых, «своих» (которые всегда поступают правильно и потому «заслуживают» положительных эпитетов) и злых, «чужих» (которые всегда осуждаются и потому требуют от певца негативно окрашенных эпитетов). Однако в русском эпосе весьма часто герои поступают неоднозначно: например, когда «свои» хвастаются, конфликтуют друг с другом (Илья и Аобрыня, Илья и Алеша, Аобрыня и Аунай, Аобрыня и Настасья, Алеша и Аобрыня, Алеша и братья Сбродовичи, Аюк и Чурила, Алеша и калики) или вызывают на бой «силу небесную» ( ККамское побоище»). Однако, даже совершая противоречивые, неоднозначные поступки, «свои» герои сохраняют «закрепленные» за ними положительные эпитеты: их «белые груди» не становятся «черными» (как у антагонистов), поездка остается «молодецкой», а сердце - «богатырским». Князь Владимир назван «ласковым» в тот момент, когда он приходит плакать на могилу заживо похороненного Потыка, однако киевский правитель характеризуется этим эпитетом и тогда, когда велит заточить Илью в темницу, проигрывает русских богатырей в «карты-шахматы» соседнему королю или сватается к жене Аанилы Аовчанина. Кроме того, значительная часть әпитетов, которые представлялись В. Я. Проппу оценочными, на самом деле «закреплены» за определяемым словом: например, «прекрасным царем»назван лютый враг русских богатырей Василий Окулович. Как известно, и «славу поют» в русском эпосе не только «своим» героям, но также антагонистам - Соловью-разбойнику (Первая поездка Ильи Муромца ... , 2003: 308), Сокольнику/Подсокольнику (Илья Муромец и Сокольник, 2003: 451), Тугарину (Алеша Попович освобождает Киев от Тугарина, 2003: 152), Змеищу/Змею (Купанье и бой Аобрыни со Змеем, 2003: 371), Издолищу/Идолищу (Встреча и поездка Ильи Муромца со Святогором ..., 2003: 589) и другим отрицательным персонажам.

Затруднительно обнаружить в былинах и оценочно окрашенные «предсказания», проявления убежденности в закономерном исходе событий (например, сделанные от лица певца предположения относительно будущей победы героя или неминуемого поражения антагониста). Аоброе или злое предсказание - отнюдь не редкость в былинах, но озвучивают его именно персонажи (матушка героя, его конь, «сухая голова» мертвого богатыря и др.), и никогда такое предсказание не звучит от самого певца как субъекта оценки. При этом «прогноз» относительно будущего далеко не всегда сбывается: например, Илья Муромец побеждает Соловья - несмотря на то, что его Бурушка спотыкается, тем самым предрекая седоку гибель.

Более того, даже в «затекстовых» ремарках былинщиков оценочные суждения встречаются редко. Так, А. Г. Игумнов обнаруживает в двухтомнике «Былины Севера» (Былины Севера, 1938-1951) всего лишь четыре ремарки с очевидной морализацией, т. е. с «ясным выражением моральной догмы или открытым осуждением» (Игумнов, 2016: 207), - и это в поздних записях советского периода, когда сказители были склонны к оценочным комментариям, подчеркивая, что воспринимают былинный этос с оговорками, с поправками на его «древность» (одна из упомянутых выше ремарок, например, была вызвана несогласием сказительницы с обязательным для былин требованием воздерживаться от хвастовства супругой). 
Отказ певцов от прямых оценок эпического поступка невозможно, конечно, объяснить национальным характером жителей Русского Севера, их природным смирением, немногословием, эмоциональной сдержанностью и т. п. Оказываясь в роли слушателей, те же северорусские крестьяне, по свидетельству собирателей эпоса, весьма часто и в самой энергичной форме высказывали свое мнение по поводу описываемых событий. Так, у А. Ф. Гильфердинга находим описание того, как некий крестьянин постоянно сопровождал исполнение былины своими замечаниями: «"Ах она мерзкая баба”, - повторял он несколько раз, слушая, как княгиня Опраксия соблазняла каличьего атамана сотворить с нею грех» (Гильфердинг, 1894: 9).

Можно предположить, что отсутствие прямых оценок со стороны певца - родовой признак подлинно художественного эпоса (общеизвестно, например, что Гомер воздерживается от оценивания поступков, совершенных его героями (Шталь, 1983: 184)). Возможно, необходимости в таких оценках просто не было - в силу существования недоступного нам «затекстового» знания (общего для певца и слушателей), создававшего единый аксиологический «фон», некую систему ценностных координат, с которой слушатель мог соотнести поступок героя и таким образом самостоятельно выработать оценку, близкую к оценке певца.

Особо отметим, что исследовать аксиологический контекст былин затруднительно потому, что живое бытование русского героического эпоса прекратилось, а собиратели старины в прошлом преимущественно фиксировали сами песни, не интересуясь тем, как поступки героев соотносятся с ценностными ориентациями певцов. Попытки реконструировать эпический контекст предпринимались неоднократно и приводили к противоположным выводам о картине мира, характерной для русского эпического сознания. Так, «ритуалисты» (в частности, Б. Н. Путилов) полагали, что эпический контекст имел отношение к ритуально-магических практикам, на которые повествование о былинных конфликтах, по мнению ученых, прямо намекало слушателям в древности (а впоследствии, когда такой контекст был утрачен в христианской среде, певцы утратили и саму возможность транслировать свою оценку аудитории). В рамках этого подхода, например, С. А. Кошарная предприняла попытку сделать «шаг к реконструкции архаичного народного мышления», изучая «исконную лексику» фольклора в качестве «транслятора архаических ментальных установок, представлений, концептуализаций» (Кошарная, 2002: 3). Прочитывая тот или иной субстантив как «микротекст», С. А. Кошарная выводила, например, из слова «мужчина» значение «Хорс, Аажьбог»; из слова «Бог»- «культ мертвых предков»; из слова «дерево» - имя божественного первопредка, Род (там же: 23).

Аругие исследователи былин, напротив, полагали, что русский героический эпос бытовал преимущественно в православной среде (О. Р. Николаев, Б. Н. Тихомиров), а следовательно, что эпическим контекстом являлись ценности воцерковленного православного христианина. Этот взгляд подтверждают исследования этнографов, показывающие высочайшую степень воцерковленности русских крестьян (Громыко, Буганов, 2000), вопреки популярной с конца 1970-х гг. гипотезе о распространенности в народе так называемого «двоеверия», «народного христианства», ценностно противостоящего якобы насаждавшемуся «официальному христианству» (Иевин, 2004). В качестве примера того, как певец имплицитно оценивает поступок героя в поле эпического контекста, логично привести эпизод из былины о Василии Буслаеве: протагонист наносит удар своему крестному отцу и при этом произносит «Христос воскрес!» (Василий Буслаев, 1863: 8); оправданно предположить, что в этом случае аудитория самостоятельно и однозначно «считывала» не- 
гативные ценностные координаты этого действия; необходимости в его прямой оценке со стороны певца не возникало.

Мы не можем опираться ни на одну из теоретических реконструкций русского эпического контекста и полагаем, что его характеристики могут быть выявлены только в результате аксиологического анализа самих былин. Сказанное тем более верно, если учесть, что расчет на контекстуальное знание слушателя не мог быть единственным способом для эпического певца реализовать свои оценки - уже потому, что былины исполнялись в том числе юношеству и детям, которые не обладали завершенным мировоззрением (ни в эпоху архаической древности, когда от них требовалось бы оценить поступки героев с позиций ритуальной практики, ни в XIX в., когда былинные певцы могли рассчитывать на самостоятельные суждения, выносимые православной аудиторией). Сказанное заставляет нас предположить, что оценка ценностного выбора, сделанного әпическим героем, осуществлялась не только с привлечением контекстуального знания слушателей.

М. М. Бахтин, обнаруживая разность оценки героя и автора в романе, полагал, что в эпосе, напротив, мировоззрение певца, героя и слушателя совпадает, т. е. герой «завершен» именно потому, что «задан» как воплощение идеалов носителя эпической традиции и его аудитории (Бахтин, 1975: 460). Если это так, то, для того чтобы выявить ценности русского эпического сознания, достаточно будет указать на ценности «любимых» народом былинных героев, установленные в результате аксиологического анализа. Однако оценка певца может проявляться не в момент ценностного выбора героя, но в отложенной перспективе, по мере наступления последствий этого выбора. Такое предположение мы можем сделать, основываясь на наблюдениях философов, изучавших связь ценностей актора (агента) с последствиями его аксиологически ориентированных поступков и указывавших на ключевую роль последствий при возникновении отношения значимости между агентом и некой ценностью1.

Очевидно, что эпическая песнь может считаться законченной (т. е. состоявшейся как взаимодействие оценок певца, героя и слушателя) лишь в том случае, если описывает не только мотивацию протагониста и его поступок, но и результаты такого поступка. Аля того чтобы песнь «состоялась» в глазах слушателя, последнему важно увидеть последствия героического действия (так, например, протагонист «Песни о Роланде» принимает решение отказаться от вызова подкрепления не потому, что задумывается о последствиях своего решения, но исключительно в связи со своими собственными представлениями о рыцарской чести, о необходимости избежать бесславия; слушателю тем не менее важно узнать, чем обернулся подвиг Роланда для Карла и Франции).

Следует подчеркнуть, что демонстрация последствий эпического поступка выражает оценку певцом не самого героя, но - ценностного выбора, сделанного героем и обретшего бытие в его поступке. Оценки одного и того же поступка самим героем (в момент совершения им поступка) и певцом (после наступления последствий этого поступка) для слушателя разнесены во времени и создают эстетическое «напряжение», которое вызвано, если можно так выразиться, разностью аксиологических потенциалов одного и того же действия в ценностном центре слушателя; эта разность обеспечивает протекание эпического нарратива от мотивации актора до последствий его поступка (например, от момента соблазна - до наказания и преображения). Тем самым обеспечивается «захват» внимания и напряженное ожидание развязки, когда слушатель (особенно тот, кто разделяет изображенный певцом 
ценностный выбор) проходит вместе с героем путь от волевого акта до ответной реакции эпического универсума на совершенный поступок (ставший отчасти поступком и самого слушателя). Певец при этом выступает не в роли механического транслятора традиционного устного текста, но в качестве носителя высшего знания о духовных законах, связывающих поступок с его последствиями, т. е. в известной мере - в ипостаси творца-демиурга былинного мира.

Таким образом, наблюдение М. М. Бахтина о тождестве оценок эпического певца и героя справедливо лишь отчасти: если мы говорим о непосредственной оценке действия накануне и в момент его совершения. Если же допустить, что этика слушателя имеет консеквенциалистский характер, то и оценочный акт певца может быть отложен и приурочен лишь к изображению им этих последствий. Аля певца в таком случае оправданно не выражать прямо свою оценку объекта, на который направлено действие агента, поскольку он обладает возможностью «заставить» героя (и, соответственно, слушателя) изменить свою первоначальную оценку через демонстрацию тех последствий, которые возымело совершенное действие. Иными словами, певец не навязывает свою оценку поступка, совершенного героем, но «навязывает» последствия этого поступка (и тогда становится ясно, что в народном эпосе певец, несмотря на диктат традиции, все же обладает определенной творческой свободой: она проявляется в выборе героя и конкретных последствий его поступков - с учетом специфики коммуникативной ситуации и, в частности, личности слушателя).

В случае наступления благих для персонажа последствий его поступка позиция мотивировавшей аксиологической категории в ценностном центре героя (и слушателя) возрастет, при этом субъективная оценка иных целей, связанных с конкурирующими ценностями, снизится. И наоборот, при наступлении дурных последствий «курс» мотивировавшей ценности относительно конкурировавших аксиологических категорий станет ниже. Аогично предположить следующее: если ценность, мотивировавшая героя, не будет девальвирована после наступления последствий совершенного им действия, то это свидетельствует о том, что укрепившаяся позиция подобной аксиологической категории в ценностном центре героя соответствует изначально неявной слушателю, но столь же высокой позиции в иерархии ценностей самого певца. Если же ценность, вызвавшая поступок героя, будет девальвирована в контексте наступивших последствий этого поступка, то вполне оправданно утверждать, что эпическое сознание осуждает подобный ценностный выбор.

Благими последствиями можно считать такие, которые привели к достижению цели, на которую был ориентирован герой: чем более эта цель связана с предельной ценностью, мотивировавшей действие, тем более благими являются последствия совершенного акта. Аурные последствия, напротив, не приводят к тому, что цель поступка, связанного с актуальной для актора предельной ценностью, оказывается достигнутой.

Аля слушателя маркером благих или дурных последствий является прежде всего то, привел ли поступок героя к его победе или поражению, к дальнейшему существованию в качестве положительного персонажа - или же к смерти. Такие последствия имеют формальный «фабульный» характер: «благим» последствием в понимании эпического певца и его слушателей является победа или выживание героя, а также обретение им свободы. «Аурным» последствием для героя может быть гибель, поражение или плен. 
Сказанное отнюдь не означает, что жизнь, победа и свобода являются конечными ценностями национального героического эпоса, а смерть, поражение и несвобода суть конечные «антиценности» русских былин. Названные положительные и отрицательные последствия играют роль «технических маркеров», указывают на «правильное» или «неправильное» поведения героя; с их помощью поступки, нацеленные на «правильные» ценности, утверждаются как таковые, а поступки, ориентированные на «антиценности», осуждаются. Это положение легко доказать: подавляющее большинство поступков, которые совершают русские эпические герои, связано со смертельным риском; следовательно, богатыри совершают эти поступки не потому, что их целью является сохранение собственной жизни. Как правило, былинный герой решает не задачу личного выживания, но изображается нацеленным на некую иную ценность, «цена» которой превышает в его понимании стоимость его собственной жизни; в этом случае выживание и победа являются, как было сказано выше, не конечной целью, но лишь сопутствующим благом, своего рода «маркером» поощрения героя свыше и одобрения эпическим певцом той цели, которую выбрал для себя богатырь, - и, следовательно, необходимым условием для продолжения героической активности.

Иными словами, жизнь и свобода (отсутствие неволи) являются не конечными ценностями, но условием того, что герой продолжит существовать именно как герой. Прекращение же бытия героя в его исходном качестве (смерть или несвобода) девальвирует ценность, вызвавшую тот или иной поступок богатыря; напротив, сама по себе возможность продолжить существование в героическом качестве есть маркер «правильного» аксиологического выбора.

Если победа состоялась, но цель, связанная с конкретной предельной ценностью (отличной от ценности жизни героя как таковой) не была достигнута, то такая победа воспринимается слушателем как бессмысленная, а эпический нарратив становится бессодержательным в аксиологическом плане.

Итак, если подавляющее большинство ценностей, мотивирующих былинных героев, укрепляется при наступлении последствий их поступков, это будет означать, что русское эпическое сознание идеализирует своих персонажей. В противном же случае мысль об идеализации эпических героев необходимо будет отвергнуть как ложную.

Чтобы выяснить, как певец оценивает ценностный выбор эпического актора, необходимо:

1) выявить для каждого поступка его цель (смысл) и связанную с этим смыслом мотивирующую ценность;

2) выявить для каждого поступка его последствия и установить, как именно изменяется «курс» мотивирующей и конкурирующих ценностей когда последствия совершенного персонажем поступка стали частью художественной реальности;

3) выявить ценности, аксиологический «курс» которых укрепляется, а также девальвируемые ценности.

\section{ЗАКАЮЧЕНИЕ}

Устраняясь от выраженной активной и морализирующей авторской позиции, русский эпический певец принимает на себя роль созерцателя и оценивает ценностный выбор героя не напрямую, но посредством подбора вариантов, демонстрирующих действие тех или иных духовных законов по модели «поступок - последствия», при этом мотивируя активную критическую деятельность слушателя, связан- 
ную с необходимостью «переоценивания» поступков, совершенных героем. Следовательно, проанализировав то, как изменяется в ценностном центре слушателя «курс» мотивировавшей героя аксиологической категории, можно получить представление о ценностном центре эпического певца и, предположительно, о структуре русского эпического мировоззрения.

\section{ПРИМЕЧАНИЕ}

${ }^{1}$ См., в частности: Платон, «Протагор» (Protagoras, 353e; Платон, 2011: 67), а также весь класс консеквенциалистских этических систем с их акцентом не на мотиве действия, но на его результате.

\section{СПИСОК АИТЕРАТУРЫ}

Адрианова-Перетц, В. П. (1974) Аревнерусская литература и фольклор. $\Lambda$. : Наука. 171 с.

Аксаков, К. С. (1856) Богатыри времен великого князя Владимира по русским песням // Русская беседа. № 4. С. 1-67.

Аксаков, К. С. (1861) О различии между сказками и песнями русскими // Полн. собр. соч. : в 3 т. Т. 1. М. : Тип. П. Бахметева. VIII, 632, II с. С. 400-408.

Алеша Попович освобождает Киев от Тугарина: [Былина] № 334 (2003) // Архангельские былины и исторические песни, собранные А. А. Григорьевым в 1899-1901 гг. с напевами, записанными посредством фонографа : в 3 т. Т. 3. СПб. : Тропа Троянова. 704 с. С. 149-152.

Аникин, В. П. (1964) Русский богатырский эпос : пособие для учителя. М. : Просвещение. 198 c.

Аникин, В. П. (1980) Теория фольклорной традиции и ее значение для исторического исследования былин. М. : Изд-во Московского ун-та. 332 с.

Аристотель (1983) Никомахова этика // Аристотель. Соч. : в 4 т. / общ. ред. А. И. Аоватура. Т. 4. М. : Мысль. 830 с. С. 53-294.

Бахтин, М. М. (1975) Эпос и роман (О методологии исследования романа) // Бахтин, М. М. Вопросы литературы и эстетики. М. : Художественная литература. 502 с. С. 447-483.

Бахтин, М. М. (2000) Эпос и роман. СПб. : Азбука. 300 с.

Бахтин, М. М. (2002) Проблемы поэтики Аостоевского // Бахтин, М. М. Собр. соч. : в 7 т. Т. 6. М. : Русские словари; Языки славянской культуры. 799 с. С. 6-300.

Бахтин, М. М. (2003а) Автор и герой в әстетической деятельности // Бахтин, М. М. Собр. соч. : в 7 т. Т. 1. Философская эстетика 1920-х годов. М. : Русские словари; Языки славянской культуры. 955 с. С. 69-264.

Бахтин, М. М. (2003b) К философии поступка // Бахтин, М. М. Собр. соч. : в 7 т. Т. 1. Философская эстетика 1920-х годов. М. : Русские словари; Языки славянской культуры. 955 с. C. 7-68.

Белинский, В. Г. (1954) Статьи о народной поэзии // Белинский В. Г. Полн. собр. соч. : в 13 т. Т. 4. М. : ИзА-во АН СССР. 863 с. С. $289-450$.

Бердяев, Н. А. (1969) Смысл истории. Париж : YMCA-Press. 268 с.

Былины Севера : в 2 т. М. ; А. : Акад. наук СССР, 1938-1951. 654, 846 с.

Василий Буслаев: [Былина] № I/1 (1863) // Песни, собранные П. В. Киреевским. Вып. 5. М. : Тип. Бахметева. 190, CXLIII с. С. 3-8.

Встреча и поездка Ильи Муромца со Святогором, смерть Святогора и освобождение Ильей Муромцем Киева от Издолища: [Былина] № 418 (2003) // Архангельские былины и исторические песни, собранные А. А. Григорьевым в 1899-1901 гг. с напевами, записанными посредством фонографа : в 3 т. Т. 3. СПб. : Тропа Троянова. 704 с. С. 584-589.

Гильфердинг, А. Ф. (1894) Олонецкая губерния и ее народные рапсоды // Онежские былины, записанные Александром Федоровичем Гильфердингом летом 1871 года : в 3 т. Т. 1. СПб. : Тип. Акад. наук. XXII, 597 с. С. 1-62. 
Горелов, А. А. (2001) Принципы издания. Состав и структура серии «Былины» Свода русского фольклора // Былины : в 25 т. Т. 1. СПб. : Наука ; М. : Классика. 776 с. С. 11-20.

Громыко, М. М., Буганов, А. В. (2000) О воззрениях русского народа. М. : Паломникъ. 541 с.

Игумнов, А. Г. (2016) Актуальная поэтика былины. Статья 2 // Вестник Бурятского государственного университета. Вып. 5. С. 199-211.

Ильин, И. А. (1993) Собрание сочинений : в 10 т. Т. 1. М. : Русская книга. 398 с.

Илья Муромец и Сокольник: [Былина] № 90 (2003) // Былины : в 25 т. Т. 3. СПб. : Наука ; М. : Классика. 531 с. С. 444-451.

Климас, И. С. (2009) Русское фольклорное слово. Курск : Изд-во Курск. гос. ун-та. 123 с.

Климас, И. С. (2010) Состав кластера «оценочные характеристики человека» в фольклорном эпосе и лирике // Традиционная культура. Т. 11. № 2 (38). С. 62-67.

Кошарная, С. А. (2002) Аингвокультурологическая реконструкция мифологического комплекса «Человек - Природа» в русской языковой картине мира : автореф. Аис. ... А-ра филол. наук. Белгород : [б. и.]. 45 с.

Купанье и бой Аобрыни со Змеем: [Былина] № 370 (2003) // Архангельские былины и исторические песни, собранные А. А. Григорьевым в 1899-1901 гг. с напевами, записанными посредством фонографа : в 3 т. Т. 3. СПб. : Тропа Троянова. 704 с. С. 369-371.

Мевин, И. (2004) Авоеверие и народная религия в истории России. М. : Индрик. 214 с.

Аихачев, А. С. (1953) Народное поэтическое творчество времени расцвета древнерусского раннефеодального государства (X-XI вв.) // Русское народное поэтическое творчество / отв. ред. В. П. Адрианова-Перетц : в 3 т. Т. 1. Очерки по истории русского народного поэтического творчества X - начала XVIII веков. М. ; $\Lambda$. : Изд-во Академии наук СССР. 538 с. C. $141-216$.

Иотман, М. Ю., Успенский, Б. А. (1996) Роль дуальных моделей в динамике русской культуры (до конца XVIII века) // Успенский, Б. А. Избранные труды : в 3 т. Т. 1. М. : Школа《Языки русской культуры». 605 с. С. 338-380.

Майков, А. Н. (1863) О былинах Владимирова цикла. СПб. : Тип. Аеп. внеш. торг. 142 с.

Мелетинский, Е. М. (1976) Поэтика мифа. М. : Наука. 407 с.

Мелетинский, Е. М. (1986) Введение в историческую поэтику эпоса и романа. М. : Наука. $318 \mathrm{c.}$

Оксенов, А. В. (1908) Народная поэзия: Былины, песни, духовные стихи: с введ. и объясн. словарем. СПб. : Синод. тип. 400, IV с.

Первая поездка Ильи Муромца: (Он спасает Чернигов, наказывает коварную девицу, встречает разбойников и укрощает Соловья-разбойника): [Былина] № 360 (2003) // Архангельские былины и исторические песни, собранные А. А. Григорьевым в 1899-1901 гг. с напевами, записанными посредством фонографа : в 3 т. Т. 3. СПб. : Тропа Троянова. 704 с. С. 298-308.

Платон (2011) Протагор // Платон. Аиалоги: Протагор, Большой Иппий, Иппий Меньший, Евтидем, Евтифрон, Апология Сократа, Критрон. М. : Академический проект. 351 с. С. 9-78.

Плисецкий, М. М. (1962) Историзм русских былин. М. : Высшая школа. 240 с.

Пропп, В. Я. (1958) Русский героический эпос. М. : Государственное издательство художественной литературы. 603 с.

Самбур, Е. В. (2010) Русская народная певческая культура: генезис и исторические трансформации : автореф. дис. ... канд. культурологии. М. : [б. и.]. 24 с.

Селиванов, Ф. М. (1983) Общественно-эстетическая функция былин // Полифункциональность фольклора / отв. ред. М. Н. Мельников. Новосибирск : НГПИ. 174 с. С. 45-57.

Серебренникова, Е. Ф. (2011) Аспекты аксиологического лингвистического анализа // Аингвистика и аксиология: этносемиометрия ценностных смыслов : кол. монография / отв. ред. $\Lambda$. Г. Викулова. М. : ТЕЗАУРУС. 351 с. С. 7-26.

Сиротинин, А. Н. (1913) Беседы о русской словесности. СПб. : Я. Башмаков и Ко. VIII, 335 с. Скафтымов, А. П. (1924) Поэтика и генезис былин. М. - Саратов : В. З. Яксонов. IV, 226 с. 
Соколов, Б. М. (1929) Новейшие труды иностранных ученых по русскому эпосу // Художественный фольклор / под ред. Ю. М. Соколова. Вып. 4-5. 226 с. С. 9-36.

Соколов, Ю. М. (1937) Русский былинный эпос (Проблема социального генезиса) // Аитературный критик. № 9. С. 171-196.

Сперанский, М. Н. (1919) Былевая песня и современные ее носители // Русская устная словесность / под ред. М. Н. Сперанского : в 2 т. Т. 2. М. : Издание М. и С. Сабашниковых. LI, 587 c. C. VII-LI.

Толстой, Н. И. (1989) Некоторые соображения о реконструкции славянской духовной культуры // Славянский и балканский фольклор: Реконструкция древней славянской духовной культуры: источники и методы / отв. ред. Н. И. Толстой. М. : Наука. 269 с. С. 7-22.

Топоров, В. Н. (1982) Модель мира (мифопоэтическая) // Мифы народов мира : энциклопедия : в 2 т. Т. 2. М. : Советская энциклопедия. 719 с.

Харитонов, В. И. (1997) Концептуальный анализ фольклорной лексики, характеризующей нравственный мир русского человека : дис. ... канд. филол. наук. Курск : [б. и.]. 166 с.

Шевырев, С. П. (1840) История русской словесности, преимущественно древней : ч. 1-4. Ч. 1. Аекция IV. М. : Унив. тип. 240 с.

Шталь, И. В. (1983) Художественный мир гомеровского эпоса. М. : Наука. 296 с.

Bowra, C. M. (1952) Heroic Poetry. London : Macmillan. IX, 590 p.

Chadwick, H. M., Chadwick, N. K. (1936) The Growth of Literature : Vols. I-II. Vol. II. Cambridge : Cambridge University Press. XVII, 783 p.

Аата поступления: 10.07.2021 2.

\section{THE VALUE NATURE OF RUSSIAN HEROIC EPICS: \\ A. S. MIRONOV \\ MosCOW STATE INSTITUTE OF CULTURE}

PROBLEMS AND PROSPECTS OF SCHOLARLY ANALYSIS

According to the author of the article, the scholars working in the field of Russian heroic epics are not yet in a position to progress towards solving the problem of bylinas' genesis and genre function, as well as the one of their relationship with mythological consciousness or the so-called folk 'praising poetry' (in Russian, velichalnaya poeziya) or different archaic rites and rituals - without resorting to the tools of the philosophy of culture, the branch of philosophy which implies comprehensive axiological analysis as one of its key methods. Such an analysis should be focused on the entire set of values motivating the actions of all Russian folk epics' heroes, as well as - hypothetically - on those worldview aspects which were common to most of the bylina narrators - in other words, on the world-conception peculiar to the epic consciousness of the Russians.

The author of the article finds that Russian epic singers assume the role of a contemplator and, as such, assess a bylina hero's value choice not directly, but through a selection of plot variants (the ones demonstrating particular spiritual laws according to the principle the deed - the consequences'), at that triggering the listener's profound critical activity related, in turn, to the necessity to reappraise the deeds made by the hero. Therefore, a study of how the 'rate' of a certain relevantfor-the-hero axiological category is modified in the listener's value centre opens up the prospects for a comprehensive axiological analysis of Russian bylinas (their value nature seen now as an interrelated unity) and implies, in particular, that Russian epic worldview is capable of being modeled.

Keywords: bylinas; comprehensive axiological analysis; values; deed; motivation; worldview; epic consciousness

\section{REFERENCES}

Adrianova-Peretc, V. P. (1974) Drevnerusskaja literatura i fol'klor. Leningrad, Nauka. 171 p. (In Russ.). 
Aksakov, K. S. (1856) Bogatyri vremen velikogo knjazja Vladimira po russkim pesnjam. Russkaja beseda, no. 4, pp. 1-67. (In Russ.).

Aksakov, K. S. (1861) O razlichii mezhdu skazkami i pesnjami russkimi. In: Aksakov, K. S. Polnoe sobranie sochinenij: in 3 vols. Vol. 1. Moscow, Printing house of P. Bakhmetev. VIII, 632, II p. Pp. 400-408. (In Russ.).

Alesha Popovich osvobozhdaet Kiev ot Tugarina: [Bylina] № 334 (2003). Arbangel'skie byliny $i$ istoricheskie pesni, sobrannye A. D. Grigor' evym v 1899-1901 gg. s napevami, zapisannymi posredstvom fonografa: in 3 vols. Vol. 3. St. Petersburg, Tropa Trojanova. 704 p. Pp. 149-152. (In Russ.).

Anikin, V. P. (1964) Russkij bogatyrskij jepos: posobie dlja uchitelja. Moscow, Prosveshhenie. 198 p. (In Russ.).

Anikin, V. P. (1980) Teorija fol'klornoj tradicii i ee znachenie dlja istoricheskogo issledovanija bylin. Moscow, Moscow State Univ. 332 p. (In Russ.).

Aristotle (1983) Nikomahova jetika. In: Aristotle. Sochinenija in 4 vols. / ed. by A. I. Dovatur. Vol. 4. Moscow, Mysl'. 830 p. Pp. 53-294. (In Russ.).

Bahtin, M. M. (1975) Jepos i roman (O metodologii issledovanija romana). In: Bahtin, M. M. Voprosy literatury $i$ jestetiki. Moscow, Hudozhestvennaja literatura. 502 p. Pp. 447-483. (In Russ.).

Bahtin, M. M. (2000) Jepos i roman. St. Petersburg, Azbuka Publ. 300 p. (In Russ.).

Bahtin, M. M. (2002) Problemy pojetiki Dostoevskogo. In: Bahtin, M. M. Sobranie socbinenij: in 7 vols. Vol. 6. Moscow, Russkie slovari; Jazyki slavjanskoj kul'tury. 799 p. Pp. 6-300. (In Russ.).

Bahtin, M. M. (2003a) Avtor i geroj v jesteticheskoj dejatel'nosti. In: Bahtin, M. M. Sobranie sochinenij: in 7 vols. Vol. 1. Filosofskaja jestetika 1920-h godov. Moscow, Russkie slovari; Jazyki slavjanskoj kul'tury. 955 p. Pp. 69-264. (In Russ.).

Bahtin, M. M. (2003b) K filosofii postupka. In: Bahtin, M. M. Sobranie socbinenij: in 7 vols. Vol. 1. Filosofskaja jestetika 1920-h godov. Moscow, Russkie slovari; Jazyki slavjanskoj kul'tury. 955 p. Pp. 7-68. (In Russ.).

Belinskij, V. G. (1954) Stat'i o narodnoj pojezii. In: Belinskij, V. G. Polnoe sobranie sochinenij: in 13 vols. Vol. 5. Moscow, Academy of Sciences of USSR. 863 p. Pp. 289-450. (In Russ.).

Berdjaev, N. A. (1969) Smysl istorii. Paris, YMCA-Press. 268 p. (In Russ.).

Byliny Severa: in 2 vols. (1938-1951) Moscow, Leningrad, Academy of Sciences of USSR. 654, 846 p. (In Russ.).

Vasilij Buslaev: [Bylina] № I/1 (1863). In: Pesni, sobrannye P. V. Kireevskim. No. 5. Moscow, Printing house of P. Bakhmetev. 190, CXLIII p. Pp. 3-8. (In Russ.).

Vstrecha i poezdka Il'i Muromca so Svjatogorom, smert' Svjatogora i osvobozhdenie Il'ej Muromcem Kieva ot Izdolishha: [Bylina] № 418 (2003). Arbangel' skie byliny i istoricheskie pesni, sobrannye A. D. Grigor' evym v 1899-1901 gg. s napevami, zapisannymi posredstvom fonografa: in 3 vols. Vol. 3. St. Petersburg, Tropa Trojanova. 704 p. Pp. 584-589. (In Russ.).

Gil'ferding, A. F. (1894) Oloneckaja gubernija i ee narodnye rhapsody. In: Onezhskie byliny, zapisannye Aleksandrom Fedorovichem Gil'ferdingom letom 1871 goda: in 3 vols. Vol. 1. St. Petersburg, Academy of Sciences. XXII, 597 p. Pp. 1-62. (In Russ.).

Gorelov, A. A. (2001) Principy izdanija. Sostav i struktura serii «Byliny» Svoda russkogo fol'klora. In: Byliny: in 25 vols. Vol. 1. St. Petersburg, Nauka; Moscow, Klassika. 776 p. Pp. 11-20. (In Russ.).

Gromyko, M. M. and Buganov, A. V. (2000) O vozzrenijab russkogo naroda. Moscow, Palomnik'. 541 p. (In Russ.).

Igumnov, A. G. (2016) Aktual'naja pojetika byliny. Stat'ja 2. Vestnik Burjatskogo gosudarstvennogo universiteta, no. 5, pp. 199-211. (In Russ.).

Il'in, I. A. (1993) Sobranie socbinenij: in 10 vols. Vol. 1. Moscow, Russkaja kniga Publ. 398 p. (In Russ.).

Il'ja Muromec i Sokol'nik: [Bylina] № 90 (2003). Byliny: in 25 vols. Vol. 3. St. Petersburg, Nauka ; Moscow, Klassika. 531 p. Pp. 444-451. (In Russ.). 
Klimas, I. S. (2009) Russkoe fol' klornoe slovo. Kursk, Kursk State Univ. 123 p. (In Russ.).

Klimas, I. S. (2010) Sostav klastera «ocenochnye harakteristiki cheloveka» v fol'klornom jepose i lirike. Tradicionnaja kul' tura, vol. 11, no. 2 (38), pp. 62-67. (In Russ.).

Kosharnaja, S. A. (2002) Lingvokul'turologicheskaja rekonstrukcija mifologicheskogo kompleksa "Chelovek - Priroda» v russkoj jazykovoj kartine mira. Abstract of dis. ... Dr. of Philology. Belgorod. 45 p. (In Russ.).

Kupan’e i boj Dobryni so Zmeem: [Bylina] № 370 (2003). Arbangel’skie byliny $i$ istoricheskie pesni, sobrannye A. D. Grigor' evymv 1899-1901 gg. s napevami, zapisannymi posredstvom fonografa: in 3 vols. Vol. 3. St. Petersburg, Tropa Trojanova. 704 p. Pp. 369-371. (In Russ.).

Levin, E. (2004) Dvoeverie i narodnaja religija v istorii Rossii. Moscow, Indrik. 214 p. (In Russ.).

Lihachev, D. S. (1953) Narodnoe pojeticheskoe tvorchestvo vremeni rascveta drevnerusskogo rannefeodal'nogo gosudarstva (X-XI vv.). In: Russkoe narodnoe pojeticheskoe tvorchestvo / ed. by V. P. Adrianova-Peretc: in 3 vols. Vol. 1. Ocherki po istorii russkogo narodnogo pojeticheskogo tvorchestva X - nachala XVIII vekov. Moscow; Leningrad, Academy of Science of USSR. 538 p. Pp. 141-216. (In Russ.).

Lotman, M. Ju. and Uspenskij, B. A. (1996) Rol' dual'nyh modelej v dinamike russkoj kul'tury (do konca XVIII veka). In: Uspenskij B. A. Izbrannye trudy: in 3 vols. Vol. 1. Moscow, Shkola «Jazyki russkoj kul'tury». 605 p. Pp. 338-380. (In Russ.).

Majkov, L. N. (1863) O bylinab Vladimirova cikla. St. Petersburg, Printing house of the Department of Foreign Trade. 142 p. (In Russ.).

Meletinskij, E. M. (1986) Vvedenie v istoricheskuju pojetiku jeposa i romana. Moscow, Nauka. 318 p. (In Russ.).

Meletinskij, E. M. (1976) Pojetika mifa. Moscow, Nauka. 407 p. (In Russ.).

Oksenov, A. V. (1908) Narodnaja pojezija: Byliny, pesni, dubovnye stibi: s vved. i ob' jasn. slovarem. St. Petersburg, Synodal Printing House. 400, IV p. (In Russ.).

Pervaja poezdka Il'i Muromca: (On spasaet Chernigov, nakazyvaet kovarnuju devicu, vstrechaet razbojnikov i ukroshhaet Solov'ja-razbojnika): [Bylina] № 360 (2003). In: Arbangel'skie byliny $i$ istoricheskie pesni, sobrannye A. D. Grigor' evym v 1899-1901 gg. s napevami, zapisannymi posredstvom fonografa: in 3 vol. Vol. 3. St. Petersburg, Tropa Trojanova. 704 p. Pp. 298-308. (In Russ.).

Platon (2011) Protagor. In: Platon. Dialogi: Protagor, Bol'shoi Ippii, Ippii Men'shii, Evtidem, Evtifron, Apologiia Sokrata, Kritron. Moscow, Akademicheskii Proekt. 351 p. Pp. 9-78. (In Russ.).

Pliseckij, M. M. (1962) Istorizm russkib bylin. Moscow, Vysshaja shkola. 240 p. (In Russ.).

Propp, V. Ja. (1958) Russkij geroicheskij jepos. Moscow, State Publishing House of Fiction. 603 p. (In Russ.).

Sambur, E. V. (2010) Russkaja narodnaja pevcheskaja kul'tura: genezis $i$ istoricheskie transformacii. Abstract of dis. ... Cand. of Culturology. Moscow. 24 p. (In Russ.).

Selivanov, F. M. (1983) Obshhestvenno-jesteticheskaja funkcija bylin. In: Polifunkcional' nost' fol'klora / ed. by M. N. Mel'nikov. Novosibirsk, Novosibirsk State Pedagogical University. 174 p. Pp. 45-57. (In Russ.).

Serebrennikova, E. F. (2011) Aspekty aksiologicheskogo lingvisticheskogo analiza. In: Lingvistika $i$ aksiologija: jetnosemiometrija cennostnyb smyslov: kollektivnaja monografija / ed. by L. G. Vikulov. Moscow, TEZAURUS. 351 p. Pp. 7-26. (In Russ.).

Sirotinin, A. N. (1913) Besedy o russkoj slovesnosti. St. Petersburg, Ja. Bashmakov i Ko. VIII, 335 p. (In Russ.).

Skaftymov, A. P. (1924) Pojetika i genezis bylin. Moscow - Saratov, V. Z. Jaksonov. IV, 226 p. (In Russ.).

Sokolov, B. M. (1929) Novejshie trudy inostrannyh uchenyh po russkomu jeposu. In: Hudozbestvennyj fol' klor / ed. by Ju. M. Sokolov. No. 4-5. 226 p. Pp. 9-36. (In Russ.). 
Sokolov, Ju. M. (1937) Russkij bylinnyj jepos. (Problema social'nogo genezisa). Literaturnyj kritik, no 9, pp. 171-196. (In Russ.).

Speranskij, M. N. (1919) Bylevaja pesnja i sovremennye ee nositeli. In: Russkaja ustnaja slovesnost' / ed. by M. N. Speranskij: in 2 vols. Vol. 2. Moscow, Izdanie M. i S. Sabashnikovyh. LI, 587 p. Pp. VII-LI. (In Russ.).

Tolstoj, N. I. (1989) Nekotorye soobrazhenija o rekonstrukcii slavjanskoj duhovnoj kul'tury. In: Slavjanskij i balkanskij fol' klor: Rekonstrukcija drevnej slavjanskoj dubovnoj kul' tury: istocbniki $i$ metody / ed. by N. I. Tolstoj. Moscow, Nauka. 269 p. Pp. 7-22. (In Russ.).

Toporov, V. N. (1982) Model' mira (mifopojeticheskaja). In: Mify narodov mira: jenciklopedija: in 2 vols. Vol. 2. Moscow, Sovetskaja jenciklopedija. 719 p. (In Russ.).

Haritonov, V. I. (1997) Konceptual'nyj analiz fol'klornoj leksiki, harakterizujushbej nravstvennyj mir russkogo cheloveka. Dis. ... Cand. of Philology. Kursk. 166 p. (In Russ.).

Shevyrev, S. P. (1840) Istorija russkoj slovesnosti, preimusbhestvenno drevnej: parts 1-4. Part 1. Lection IV. Moscow, Univ. printing House. 240 p. (In Russ.).

Shtal', I. V. (1983) Hudozhestvennyj mir gomerovskogo jeposa. Moscow, Nauka. 296 p. (In Russ.).

Bowra, S. M. (1952) Heroic Poetry. London, Macmillan. IX, 590 p.

Chadwick, H. M. and Chadwick, N. K. (1936) The Growth of Literature: in 2 vols. Vol. 2. Cambridge, Cambridge University Press. XVII, 783 p.

Submission date: 10.07 .2021$.

Миронов Арсений Станиславович - кандидат филологических наук, доцент кафедры народной художественной культуры Московского государственного института культуры. Адрес: 141406, Россия, г. Химки, ул. Библиотечная, д. 7. Тел.: 8 (495) 570-04-77. Эл. адрес: arsenymir@yandex.ru

Mironov Arseny Stanislavovich, Candidat of Philology, Associate Professor, Department of Folk Artistic Culture, Moscow State Institute of Culture. Postal address: 7, Bibliotechnaya St., Khimki, Russian Federation, 141406. Tel.: 8 (495) 570-04-77. E-mail: arsenymir@yandex.ru 